\title{
Two new species of subgenus Avaritia of the Culicoides biting midges (Diptera: Ceratopogonidae) from Japan
}

\author{
Takao Kanasugi ${ }^{1)}$ and Shigeo KitaokA ${ }^{2)}$ \\ 1) Gunma Insect World Construction Office, Ote-machi, 1-1-1, Maebashi, Gunma, 371-8570 Japan \\ 2) Kashiwazaki, 1279-215, Niigata, 945-1102 Japan
}

(Received: 27 March 2001; Accepted: 2 August 2001)

\begin{abstract}
Key words: Avaritia, Ceratopogonidae, Culicoides nupurius sp. n., Culicoides hasegawai sp. n., taxonomy
\end{abstract}

\begin{abstract}
Two new species of Culicoides biting midges belonging to the subgenus Avaritia, the female of $C$. nupurius sp. n. from Tokachi and Kamikawa districts, Hokkaido and the male of $C$. hasegawai sp. n. from Iwate prefecture, Honshu are described and illustrated.
\end{abstract}

\section{INTRODUCTION}

The viruses of bluetongue, ephemeral fever and Akabane disease of cattle and wild or domestic ruminants have been isolated from several species of Culicoides of the subgenus Avaritia from Africa, South Asia and Japan (Wirth and Hubert, 1989). The rich Avaritia fauna of Japan is noteworthy, which contains 18 species (Kitaoka, 1984; Wada, 1999) including recent records of $C$. orientaris from southern Kyushu, compared with 8 from America (Wirth et al., 1985), 10 from Russia (Glukhova, 1989), 17 from South Asia (Wirth and Hubert, 1989) and 14 from Taiwan (Lien et al., 1998), respectively.

The subgenus Avaritia is relatively uniform in morphological characters and is distinguishable from the other subgenera definitively. The present paper describes two additional new Culicoides (Avaritia) species from Hokkaido and northern Honshu, Japan.

The holotype specimens used for the following description are deposited in the National Science Museum (Natural History), Tokyo, Japan.

\section{Materials AND Methods}

All specimens were collected by light traps and mounted with phenol-balsam for microscopic examination. Values of measurement were given in $\mathrm{mm}$ or $\mu \mathrm{m}$ by mean and in parentheses, ranges.

\section{DESCRIPTION}

Culicoides (Avaritia) nupurius sp. n. (Japanese name: Nupuri-nukaka)

Female (Figs. 1A-1E): Body brown, medium-sized, about $1.8-2.2 \mathrm{~mm}$ in length.

Head: Eyes contiguous for about two facets (Fig. 1B), bare. Antenna (Fig. 1C) with lengths of flagellar segments in proportion of $46: 27: 27: 32: 30: 32: 32: 35$ : $50: 49: 47: 60: 90$ ( $\mu \mathrm{m}$ unit), total length $578(535-619, \mathrm{n}=7) ; \mathrm{AR}$ (antennal ratio $=$ length of segments $11-15 /$ length of segments $3-10) 1.16(1.04-1.25, \mathrm{n}=7)$; sensilla coeloconica present on segments $3,11-15$, number of sensilla on each segment $3,1,1$, $1,2,1(\mathrm{n}=3)$. Palpal segments (Fig. 1D) in proportion of $15: 61: 61: 30: 32$ ( $\mu \mathrm{m}$ unit), PR (Palpal Ratio=length of segment 3/ breadth of segment 3) 3.1 ; third segment slightly swollen, with sensilla on a shallow 
sensory pit. Proboscis moderately long, $\mathrm{P} /$ $\mathrm{H}$ Ratio (proboscis length/head length) $0.80(0.76-0.82, \mathrm{n}=4)$; mandible with 12 to 16 teeth.

Thorax: Brown, scutellum with a pair of each of midscutellar and lateral bristles.

Legs: Brown, hind tibial comb with five spines, the one nearest the spur longest.

Wing (Fig. 1A): Length 1.17 (1.00-1.26, n $=7) \mathrm{mm}, \mathrm{CR}$ (costal length/wing length) $0.61(0.60-0.63, n=7)$. Pattern as figured, slightly infused, pale spots very faint; a pale spot over r-m cross vein small, not reaching costal margin; post stigmatic pale spot small. Macrotrichia sparse and located near wing margin in apices of cells R5, M1 and M2. Halter pale.

Abdomen: Brown, spermathecae (Fig. 1 E) two, pigmented, ovoid, subequal, tapering to short scleroitzed necks; each measuring 0.055 by $0.045,0.060$ by $0.040 \mathrm{~mm}$; a rudimentary spermatheca present.

Male: Unknown.

Holotype: Female, Tottabetsu, Tokachi, Hokkaido, 10-VII-1990, Ken Kuriki leg.

Paratypes: 1 female, Shirogane spa, Kamikawa, Hokkaido, 28-VIII-1984, Hirofumi Hayakawa leg. 1 female, Tottabetsu, Tokachi, Hokkaido, 12-VIII-1990, K. Kuriki leg. 4 females, Shikaribetsu, Tokachi, Hokkaido, 19-VIII-1990, K. Kuriki leg.

Remarks: The wing pattern of $C$. nupurius sp. n. is similar to Holarctic species, $C$. chiopterus (Meigen, 1830) but much larger and lacks interfacetal hairs. The present new species was collected from natural forests distributed at altitude of 450 to $850 \mathrm{~m}$ in the Daisetsu and Hidaka mountain ranges, Hokkaido.

Culicoides (Avaritia) hasegawai sp. n. (Japanese name: Hasegawa-nukaka)

Female: Unknown.

Male (Figs. 2 A-2 C): Body brown, medium sized about $2.3 \mathrm{~mm}$ in length.

Head: Eyes contiguous for two facets, bare. Antenna with length of flagellar segment in proportion of $85: 41: 41: 43: 42$ : $40: 42: 40: 45: 40: 122: 113: 115(\mu \mathrm{m}$
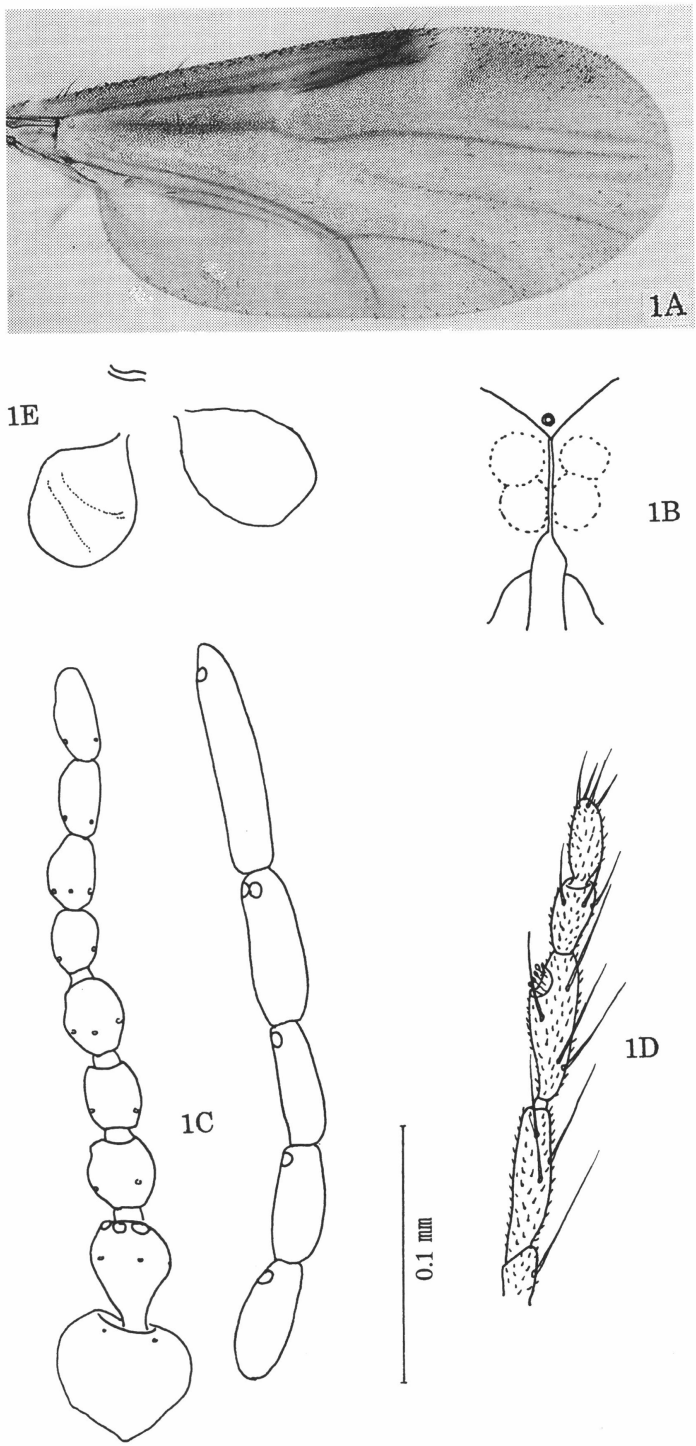

Fig. 1. Culicoides nupurius sp. n. (female). A, wing; B, fronto-vertex; C, antenna; D, palpus; E, spermathecae.

unit); sensilla coeloconica present on segments 3, 13-15; number of sensilla on each segment 2, 1, 3, 3. Palpal segments (Fig. 2 B) in proportion of $23: 53: 50: 26: 35(\mu \mathrm{m}$ unit), PR 2.9; third segment with a small shallow sensory pit.

Wing (Fig. 2A): Length $1.25 \mathrm{~mm}$. Pattern as figured, faint, pale spot over $\mathrm{r}-\mathrm{m}$ cross vein covering vein $\mathrm{M}$ posteriorly; poststigmatic pale spot in cell R5 covering distal half of second radial cell, broadest 
anteriorly at wing margin; large pale spot at apex of cell R5; cells M1, M2, M4 and anal cell each with a large pale spot.

Genitalia (Fig. 2C): Ninth sternum broad with deep and narrow caudomedian excavation, ventral membrane bare, ninth tergum rounded distally with slight caudomedian cleft. Basistyle with long and curved ventral root; dorsal root shorter; dististyle slightly curved and moderately slender, slightly swollen at the apex. Aedeagus with sub-triangular basal arch; distal process moderately long. Parameres separate, with moderately long and swollen basal arm, tapering distally to a simple pointed tip.

Holotype: Male, Shizukuishi, Iwate pref., Honshu, 15-VII-1898, Tsutomu Hasegawa leg.

Remarks: The wing pattern as figured of C. hasegawai sp. n. is similar to that of $C$. obsoletes or $C$. sinanoensis group, but the genitalia completely different in structure. The structure of aedeagus of male genitalia is relatively similar to that of $C$. motoensis Lee, 1979 from Tibet but differs from it by lack of distal process.

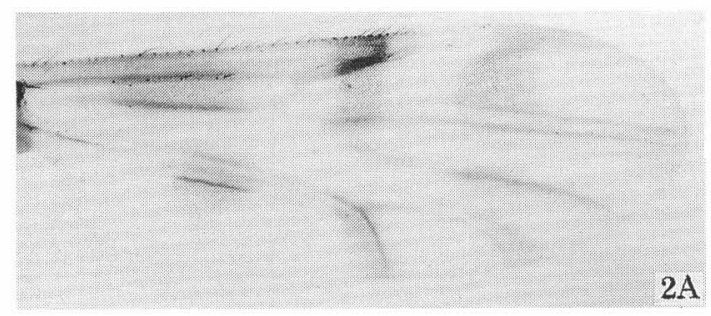

\section{ACKNOWLEDGEMENTS}

The authors wish to express their thanks to Dr. T. Hasegawa of Morioka City and Mr. K. Kuriki of Veterinary Representative, Kyoritsu Shoji Co., Tokyo, for providing us with specimens. We are also grateful to Prof. H. Matsuda and Dr. Y. Chigusa of Department of Tropical Medicine and Parasitology, Dokkyo University School of Medicine, for their kind permission to use the laboratory and to Dr. Y. Wada for providing useful references.

\section{REFERENCES}

Glukhova, V. M. 1989. Blood sucking midges of genus Culicoides and Forcipomyia (Ceratopogonidae), Fauna USSR, 3, Part 5a: 1-406. (in Russian).

Kitaoka, S. 1984. Japanese Culicoides (Diptera: Ceratopogonidae) and keys for the species I. Bull. Nat. Inst. Anim. Health, 87: 73-89 (in Japanese).

Lien, J. C., Weng, H. H. and Lin, C. C. 1998. A revision of the genus Culicoides in Taiwan II. Subgenus Avaritia (Diptera: Ceratopogonidae). J. Taiwan Mus., 51: 21-48.

Wada, Y. 1999. Culicoides biting midges of Japan (Diptera: Ceratopogonidae). Trans. Nagasaki Biol. Soc., 50: 45-70 (in Japanese).

Wirth, W. W., Dyce, A. L. and Peterson, B. P. 1985. An atlas of wing photographs, with a summary of the numerical characters of Nearctic species of Culicoides (Diptera: Ceratopogonidae). Contrib. Am. Entomol. Inst., 22: 1-46.

Wirth, W. W. and Hubert, A. H. 1989. The Culicoides of Southeast Asia (Diptera: Ceratopogonidae). Mem. Am. Entomol. Inst., 44: 1-508.

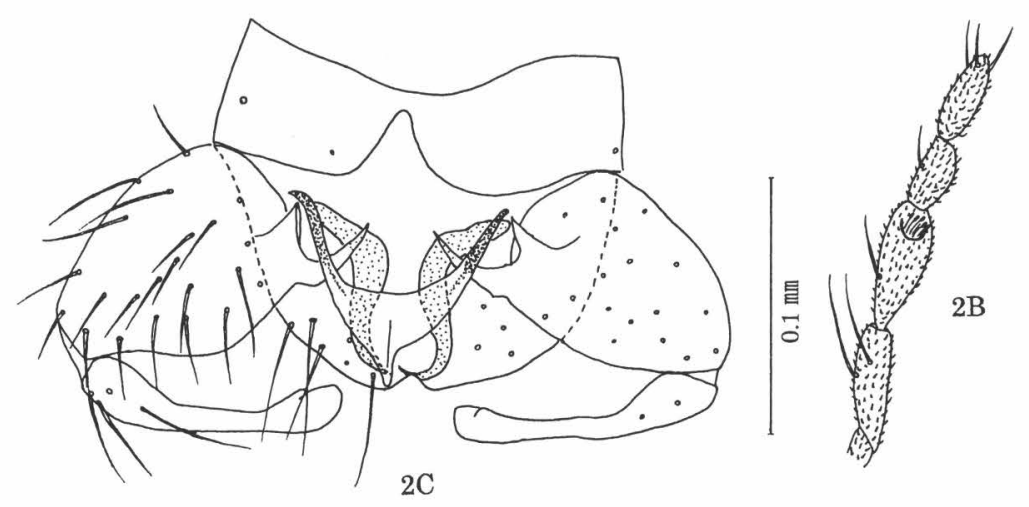

Fig. 2. Culicoides hasegawai sp. n. (male). A, wing; B, palpus; C, genitalia. 